\title{
Korelasi Internet Gaming Disorder Terhadap Kualitas Tidur pada Mahasiswa Fakultas Kedokteran UKRIDA Tahun Ajaran 2018/2019
}

\author{
Januwar Lukita1, William², Indriani K Sumadikarya², Flora Rumiati² \\ ${ }^{1}$ Fakultas Kedokteran dan Ilmu Kesehatan, Universitas Kristen Krida Wacana, Jakarta, Indonesia. \\ ${ }^{2}$ Departemen Fisiologi Fakultas Kedokteran dan Ilmu Kesehatan Universitas Kristen Krida Wacana, Jakarta, \\ Indonesia. \\ Alamat Korespondensi: flora.rumiati@ukrida.ac.id
}

\begin{abstract}
Abstrak
Internet gaming disorder merupakan salah satu bentuk penggunaan internet yang secara berkelanjutan yang bersifat patologis. Salah satu kerugian yang dapat terjadi adalah terganggunya kualitas tidur seseorang dikarenakan waktu tidur yang dikobankan untuk bermain game. Penelitian ini bertujuan untuk mengetahui korelasi internet gaming disorder terhadap kualitas tidur mahasiswa Fakultas Kedokteran Universitas Kristen Krida Wacana. Penelitian ini adalah penelitian analitik dengan purposive sampling pada 88 orang responden yang terdiri dari mahasiswa angkatan 2015, 2016, 2017 , dan 2018 di Fakultas Kedokteran UKRIDA. Kuesioner Internet Gaming Disorder Short-Scale Form (IGD9S-SF) digunakan untuk menentukan kejadian internet gaming disorder dan kuesioner Pittsburgh's Sleep Quality Index (PSQI) digunakan untuk menilai kualitas tidur responden. Analisis data dilakukan dengan menggunakan SPSS versi 24. Sebanyak $87 \%$ responden memiliki kualitas tidur yang buruk, dan dari responden yang memiliki kualitas tidur buruk didapatkan sebanyak $9,1 \%$ mengalami internet gaming disorder. Dalam penelitian ini internet gaming disorder memiliki korelasi lemah terhadap kualitas tidur mahasiswa FK UKRIDA.
\end{abstract}

Kata kunci: gangguan tidur, internet gaming disorder, kualitas tidur, neurotransmitter

\section{Correlation Between Internet Gaming Disorder and Sleep Quality of Ukrida Medical Students from Academic Year 2018/2019}

\begin{abstract}
Internet gaming disorder is a form of pathologically continuous internet usage. One of the disadvantages of this disorder is a disruption of sleep quality due to shorter duration of sleep. This study aimed to determine the correlation between internet gaming disorder and sleep quality among students at the Faculty of Medicine, Krida Wacana Christian University. This study is an analytical study with purposive sampling on 88 respondents, consisting of students from 2015, 2016, 2017, and 2018 intakes at the UKRIDA Faculty of Medicine. The Internet Gaming Disorder Short-Scale Form (IGD9S-SF) questionnaire was used to determine the incidence of internet gaming disorder and the Pittsburgh's Sleep Quality Index (PSQI) questionnaire was used to assess the sleep quality among respondents. Data analysis was performed using SPSS version 24. As many as $87 \%$ of respondents had poor sleep quality, and among these respondents, $9.1 \%$ experienced an internet gaming disorder. In this study internet gaming disorder had a weak correlation with the quality of sleep.
\end{abstract}

Keywords: sleep disturbance, internet gaming disorder, sleep quality, neurotransmitte 


\section{Pendahuluan}

Tidur adalah bagian yang penting dalam aktivitas sehari-hari. Manusia menghabiskan sekitar sepertiga waktu hidup nya untuk tidur. Memiliki kualitas tidur yang baik, sama pentingnya seperti membutuhkan makanan dan air untuk kelangsungan hidup. Tanpa tidur, manusia akan kesulitan menjaga jalur persarafan di otak yang memungkinkan untuk belajar, mengingat hal-hal baru, dan lebih sulit untuk berkonsentrasi serta merespons sesuatu dengan cepat. ${ }^{1}$

Waktu ketika beraktivitas dan ketika tubuh membutuhkan tidur diatur oleh jam biologis tubuh. Jam biologis tubuh tersusun dari protein yang berinteraksi dalam sel di seluruh tubuh. ${ }^{2}$ Jam biologis ini memiliki siklus sekitar 24 jam. Jam biologis tubuh menghasilkan dan mengatur irama sirkadian. ${ }^{3}$

Irama sirkadian adalah perubahan fisik, mental, dan perilaku yang mengikuti siklus harian. Tidur di malam hari dan terjaga di siang hari adalah contoh irama sirkadian terkait cahaya. ${ }^{2}$ Ketika malam hari jumlah cahaya lebih sedikit, sehingga suprachiasmatic nucleus (SCN) memberi sinyal ke otak untuk memproduksi lebih banyak hormon melatonin sehingga menimbulkan kantuk. ${ }^{4}$ Irama sirkadian juga dapat memengaruhi pelepasan hormon, kebiasaan makan, pencernaan, suhu tubuh, dan fungsi penting lainnya. Irama sirkadian yang tidak teratur telah dikaitkan dengan berbagai kondisi kesehatan kronis, seperti gangguan tidur, obesitas, diabetes, depresi, dan gangguan bipolar. ${ }^{2}$

Di Indonesia, prevalensi insomnia sekitar $10 \%$, yang berarti 28 juta orang dari total 238 juta penduduk Indonesia menderita insomnia. ${ }^{5}$ Pada tahun 2012, komunitas peneliti yang bekerjasama dengan Akademi Ilmu Pengetahuan Indonesia (AIPI) melakukan penelitian tentang prevalensi kecanduan game dan dapat diperkirakan prevalensi orang yang mengalami kecanduan game diantara pemain game sekitar $6,1 \%$ di Indonesia. ${ }^{6}$ Online game atau internet gaming adalah video game yang sebagian besar dimainkan menggunakan internet atau jaringan komputer lain yang tersedia. ${ }^{7}$ Internet gaming dapat dibagi menjadi dua jenis, yaitu Massively Multiplayer Online Games (MMOs) dan Massively Multiplayer
Online Role-Playing Games (MMORPGs). ${ }^{8}$

Sampai dengan Juni 2019, game seperti Mobile Legends: Bang Bang, Garena Free Fire: Rampage, Clash of Clans, dan PlayerUnknown's Battlegrounds Mobile menempati urutan 4 besar mobile game yang paling diminati di Indonesia. ${ }^{9}$ Pada 2013 internet gaming disorder dimasukkan dalam klasifikasi gangguan mental dan perilaku dari American Psychiatric Association (DSM-5) sebagai syarat untuk studi lebih lanjut. ${ }^{10}$ Pada September 2018, WHO mengumumkan bahwa internet gaming disorder didefinisikan dalam revisi ke-11 International Classification of Diseases (ICD-11) sebagai pola perilaku permainan (digital-gaming atau video-gaming) yang ditandai oleh gangguan kontrol atas game, meningkatkan prioritas yang diberikan untuk bermain game alih-alih aktivitas lain sejauh game lebih diutamakan daripada minat dan aktivitas harian lainnya, dan kelanjutan atau peningkatan permainan meskipun terjadi konsekuensi negatif. ${ }^{11}$

Berdasarkan tanda-tanda yang ditimbulkan internet gaming disorder, dikhawatirkan akan mengganggu waktu tidur seseorang, maka penelitian ini dilakukan untuk mengetahui apakah ada korelasi antara internet gaming disorder dengan kualitas tidur.

\section{Metodologi Penelitian}

Penelitian ini dilakukan dengan pendekatan cross-sectional pada mahasiswa Fakultas Kedokteran Universitas Kristen Krida Wacana Tahun Ajaran 2018/2019. Pengambilan sampel dengan purposive sampling denganbesar sampel sebanyak 88.Kriteria inklusi yang digunakan mahasiswa angkatan 2015-2018 yang bermain game online. Kriteria eksklusi yang digunakan responden yang rutin minum kopi atau alkohol, merokok dan kuisonernya tidak lengkap. Data dideskripsikan ke dalam tabel menggunakan program Microsoft Excel. Untuk mengetahui normalitas data dilakukan uji KolmogorovSmirnov dan didapatkan data berdistribusi normal. Untuk mengetahui korelasi antara variabel internet gaming disorder dengan variabel kualitas tidur dilakukan uji korelasi Pearson. 


\section{Hasil Penelitian}

Penelitian ini dilakukan di Fakultas Kedokteran Universitas Kristen Krida Wacana yang dilakukan pada mahasiswa-mahasiswi semester 1, 3, 5, dan 7 tahun ajaran 2018/2019. Responden adalah mahasiswa angkatan 20152018 yang berdasarkan perhitungan sampel, maka responden yang diambil sejumlah 88 mahasiswa. Dari 88 orang ini, 69 di antaranya berjenis kelamin laki-laki, dan 19 orang berjenis kelamin perempuan. Sebagian besar responden memiliki rentang usia 19-20 tahun $(40,1 \%)$.

\section{Tabel 1. Karakteristik Umum Responden}

\begin{tabular}{lcc}
\hline & $\mathrm{n}=88$ & Presentase (\%) \\
\hline Angkatan & & \\
2015 (Semester 7) & 34 & 38,5 \\
2016 (Semester 5) & 18 & 20,5 \\
2017 (Semester 3) & 18 & 20,5 \\
2018 (Semester 1) & 18 & 20,5 \\
\hline Jenis Kelamin & 69 & 78,4 \\
Pria & 19 & 21,6 \\
Wanita & & \\
Usia & 16 & 18,1 \\
17-18 tahun & 35 & 40,1 \\
19-20 tahun & 34 & 38,5 \\
21-22 tahun & 3 & 3,3 \\
23-24 tahun & &
\end{tabular}

Tabel 2. Gambaran Internet Gaming Disorder Mahasiswa FKIK UKRIDA Tahun Ajaran 2018/2019

\begin{tabular}{lcccccc}
\hline \multirow{2}{*}{ Jenis Kelamin } & \multicolumn{3}{c}{ Internet Gaming Disorder } & \multicolumn{2}{c}{ Total } \\
& \multicolumn{2}{c}{ Ya } & \multicolumn{2}{c}{ Tidak } & \multicolumn{2}{c}{ \% } \\
& $\mathrm{n}$ & $\%$ & $\mathrm{n}$ & $\%$ & $\mathrm{n}$ & $\%$ \\
\hline Pria & 6 & 6,8 & 63 & 71,6 & 69 & 78,4 \\
Wanita & 2 & 2,3 & 17 & 19,3 & 19 & 21,6 \\
\hline Total & 8 & 9,1 & 80 & 90,9 & 88 & 100 \\
\hline
\end{tabular}

Pada tabel 2. menggambarkan dari total 88 responden didapatkan sebanyak 8 responden atau sebanyak $9,1 \%$ mengalami internet gaming disorder. Ditinjau dari jenis kelamin, jumlah responden pria yang mengalami internet gaming disorder sebanyak 6 responden sedangkan jumlah responden perempuan yang tergolong mengalami internet gaming disorder sebanyak 2 responden. Sebanyak 6,8\% dari total responden pria dan $2,3 \%$ dari total responden wanita mengalami internet gaming disorder. Hasil ini menggambarkan responden pria lebih banyak memiliki internet gaming disorder daripada wanita pada populasi sampel.

Tabel 3. Gambaran Waktu Pergi Tidur Pada Mahasiswa FKIK UKRIDA Tahun Ajaran 2018/2019

\begin{tabular}{|c|c|c|c|c|c|}
\hline & & Jumlah & & & \\
\hline Waktu Pergi Tidur & $\mathrm{n}$ & & $\%$ & & \\
\hline $22.00-23.59$ & 22 & & 25 & & \\
\hline $24.00-01.59$ & 51 & & 58 & & \\
\hline$\geq 02.00$ & 15 & & 17 & & \\
\hline Total & 88 & & 100 & & \\
\hline $\begin{array}{l}\text { Pada tabel 3. tampak sebagian besar } \\
\text { responden memiliki waktu pergi tidur antara }\end{array}$ & $\begin{array}{l}\text { puku } \\
\text { resp }\end{array}$ & $\begin{array}{l}24.00-01.59 \\
\text { den }(58 \%)\end{array}$ & yaitu & sebanyak & 51 \\
\hline
\end{tabular}


Tabel 4. Gambaran Waktu Bangun Tidur pada Mahasiswa FKIK UKRIDA Tahun Ajaran 2018/2019

\begin{tabular}{lcc}
\hline Waktu Bangun Tidur & $\mathrm{n}$ & Jumlah \\
& 19 & $\%$ \\
$04.00-05.59$ & 61 & 22 \\
$06.00-07.59$ & 8 & 69 \\
$\geq 08.00$ & 88 & 9 \\
\hline Total & & 100 \\
\hline
\end{tabular}

Pada tabel 4. tampak sebagian besar responden memiliki waktu bangun antara pukul $06.00-07.59$ yaitu sebanyak 61 responden atau
69\%. Perkuliahan di FK UKRIDA dimulai pukul 07.30.

Tabel 5. Gambaran Waktu yang Dibutuhkan Untuk Terlelap pada Mahasiswa FKIK UKRIDA Tahun Ajaran 2018/2019

\begin{tabular}{ccc}
\hline Waktu yang dibutuhkan & Jumlah & \\
untuk terlelap (menit) & $\mathrm{n}$ & $\%$ \\
\hline$\leq 15$ & 34 & 39 \\
$16-30$ & 25 & 28 \\
$31-60$ & 24 & 27 \\
$>60$ & 5 & 6 \\
\hline Total & 88 & 100 \\
\hline
\end{tabular}

Pada tabel 5. tampak waktu yang dibutuhkan untuk terlelap terbanyak ialah $\leq 15$ menit yaitu sebanyak 34 responden. Terdapat 5 responden yang membutuhkan waktu lebih dari
60 menit di Kasur untuk dapat terlelap. Ratarata waktu yang dibutuhkan untuk terlelap responden adalah 35 menit.

Tabel 6. Gambaran Durasi Tidur pada Mahasiswa FKIK UKRIDA Tahun Ajaran 2018/2019

\begin{tabular}{ccc}
\hline $\begin{array}{c}\text { Durasi Tidur } \\
(\text { Jam })\end{array}$ & $\mathrm{n}$ & Total \\
\hline$<6$ & 44 & $\%$ \\
$6-7$ & 43 & 48,9 \\
$>7$ & 1 & 1,1 \\
\hline Total & 88 & 100 \\
\hline
\end{tabular}

Pada tabel 6. tampak jumlah responden yang memiliki durasi tidur $<6$ jam sebanyak 44 responden. Jumlah ini tidak jauh berbeda dengan jumlah responden yang memiliki durasi tidur 6-7 jam sebanyak 43 responden. Rata-rata durasi tidur responden selama 5,5 jam.

Tabel 7. Masalah yang Mengganggu Tidur pada Mahasiswa FKIK UKRIDA Tahun Ajaran 2018/2019

\begin{tabular}{lcc}
\hline Masalah yang Mengganggu Tidur & Jumlah & $\%$ \\
\hline Tidak dapat tidur selama 30 menit & 68 & 77,2 \\
Terbangun di malam hari atau bangun terlalu cepat & 60 & 68,1 \\
Mengalami mimpi buruk & 58 & 65,9 \\
Terbangun karena ingin BAK/BAB & 56 & 63,6 \\
Kedinginan di malam hari & 51 & 57,9
\end{tabular}


Tabel 7 menggambarkan faktor-faktor yang mengganggu tidur pada responden secara urut dari yang paling banyak dialami, yaitu tidak dapat tidur selama 30 menit sebanyak 68 responden $(77,2 \%)$, hingga yang paling sedikit akibat alasan lain sebanyak 11 responden $(12,5 \%)$. Alasan lain yang mengganggu tidur yang dituliskan responden adalah stress karena adanya PBL dan ujian, suara berisik, atau cahaya lampu terlalu terang.

\section{Tabel 8. Konsumsi Obat Tidur pada Mahasiswa FKIK UKRIDA Tahun Ajaran 2018/2019}

\begin{tabular}{lcc}
\hline $\begin{array}{l}\text { Frekuensi Konsumsi Obat Tidur } \\
\text { dalam Seminggu }\end{array}$ & Total & \\
\hline$<1 \mathrm{x}$ & 0 & 0 \\
$1-2 \mathrm{x}$ & 7 & 8 \\
$\geq 3 \mathrm{x}$ & 1 & 1 \\
Tidak konsumsi dalam sebulan terakhir & 80 & 91 \\
\hline Total & 88 & 100 \\
\hline
\end{tabular}

Pada Tabel 8, sebanyak 9\% dari total 88 responden Mahasiswa FK Ukrida menggunakan obat-obatan untuk membantu tidur selama sebulan terakhir dan semuanya mempunyai kualitas tidur yang buruk.

\section{Tabel 9. Frekuensi Terjadinya Masalah Akibat Kurang Tidur atau Mengantuk pada Mahasiswa FKIK UKRIDA Tahun Ajaran 2018/2019}

\begin{tabular}{lcc}
\hline Frekuensi Terjadinya Masalah Akibat & Total \\
Kurang Tidur atau Mengantuk & $\mathrm{n}$ & $\%$ \\
\hline$<1 \mathrm{x}$ dalam seminggu & 3 & 3 \\
$1-2 \mathrm{x}$ dalam seminggu & 35 & 40 \\
$\geq 3 \mathrm{x}$ dalam seminggu & 50 & 57 \\
\hline Total & 88 & 100 \\
\hline
\end{tabular}

Tabel 9 menggambarkan frekuensi terjadinya masalah-masalah yang dapat mengganggu responden saat mengendarai kendaraan, makan atau beraktivitas sosial akibat mengantuk atau kurang tidur. Dari tabel di atas, didapatkan sebanyak $57 \%$ responden $\geq$ $3 x$ dalam seminggu mengalami masalah akibat kurang tidur atau mengantuk. Sebanyak 3\% responden $<1 \mathrm{x}$ dalam seminggu mengalami masalah akibat kurang tidur atau mengantuk.

Tabel 10. Perasaan Kualitas Tidur Subjektif Mahasiswa FKIK UKRIDA Tahun Ajaran 2018/2019 Dalam Satu Bulan Terakhir

\begin{tabular}{lcc}
\hline Perasaan Kualitas Tidur Subjektif & Total & $\%$ \\
\hline Sangat Baik & $\mathrm{n}$ & 6,8 \\
Baik & 6 & 48,9 \\
Buruk & 43 & 38,6 \\
Sangat Buruk & 34 & 5,7 \\
\hline Total & 5 & 100 \\
\hline Lukita J, William, Sumadikarya I dan Rumiati F. 2020;26(1):8-16 & 88 &
\end{tabular}


Pada Tabel 10, tampak sebagian besar responden secara subjektif menilai kualitas tidurnya baik, yaitu sebanyak 43 responden
$(48,9 \%)$. Sedangkan responden yang menilai kualitas tidurnya buruk selama sebulan terakhir sebanyak 34 responden atau

\section{Tabel 11. Kualitas Tidur Mahasiswa FKIK UKRIDA Tahun Ajaran 2018/2019 Berdasarkan}

PSQI

\begin{tabular}{lcccccc}
\hline \multirow{2}{*}{ Jenis Kelamin } & \multicolumn{3}{c}{ Kualitas Tidur } & \multicolumn{2}{c}{ Total } \\
& $\mathrm{n}$ & $\%$ & $\mathrm{n}$ & $\%$ & $\mathrm{n}$ & $\%$ \\
\hline Pria & 1 & 1,4 & 68 & 98,6 & 69 & 100 \\
Wanita & 0 & 0 & 19 & 100 & 19 & 100 \\
\hline Total & 1 & 1,4 & 87 & 98,6 & 88 & 100 \\
\hline
\end{tabular}

Pada Tabel 11, tampak dari 88 responden didapatkan sebanyak sebanyak 87 responden atau sebanyak $98,6 \%$ mempunyai kualitas tidur yang buruk. Ditinjau dari jenis kelamin, jumlah responden pria yang memiliki kualitas tidur buruk sebanyak 68 responden sedangkan jumlah responden wanita yang memiliki kualitas tidur buruk sebanyak 19 responden.

\section{Korelasi Internet Gaming Disorder dengan Kualitas Tidur Mahasiswa Fakultas Kedokteran UKRIDA}

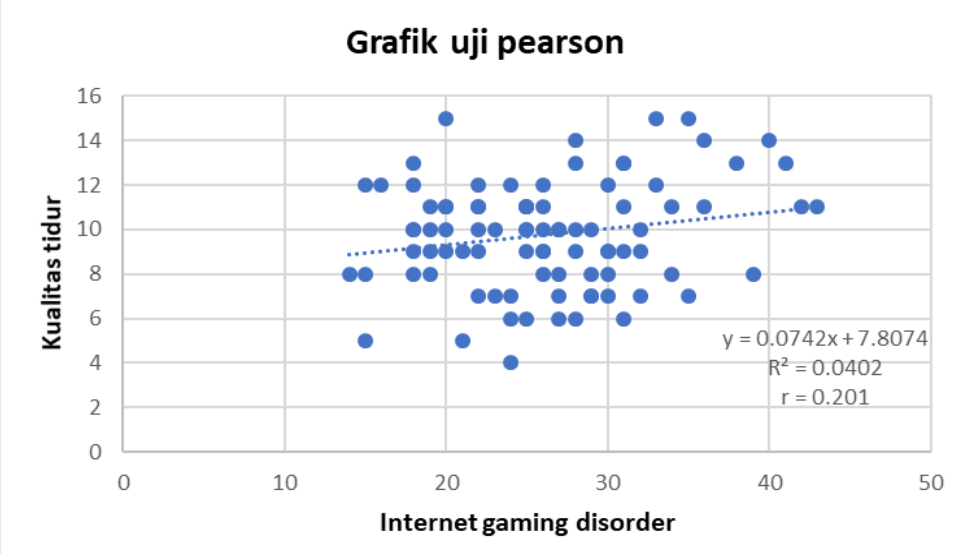

Grafik 1. Uji Pearson Internet Gaming Disorder dengan Kualitas Tidur

Grafik 1 menunjukkan angka koefisien korelasi pearson didapatkan sebesar +0.201 , artinya memiliki arah korelasi positif, dan besar korelasi antara variabel internet gaming disorder dan kualitas tidur memiliki korelasi lemah.

\section{Pembahasan}

Dari penelitian ini, diperoleh $9,1 \%$ dari responden mengalami gangguan internet gaming disorder. Hasil 9,1\% pada penelitian ini hampir sama dengan penelitian yang dilakukan oleh Maya Samaha pada tahun 2018, terhadap 524 remaja di Libanon dengan prevalensi 9,2\% mengalami internet gaming disorder ${ }^{13,14}$ Hasil
9,1\% pada penelitian ini hampir mirip dengan penelitian yang dilakukan oleh Choo pada tahun 2010, terhadap 2998 remaja di Singapura dengan prevalensi 8,7\% mengalami internet gaming disorder. ${ }^{15}$ Hasil penelitian ini juga tidak jauh berbeda dengan penelitian yang dilakukan oleh Spekman, Konijn, Roelofsma, dan Griffiths pada tahun 2013, terhadap 1004 remaja di Belanda dimana didapatkan prevalensi $8,57 \%$ mengalami internet gaming disorder. ${ }^{16}$ Pada penelitian yang dilakukan oleh Hussain tentang klasifikasi kecanduan game online dan faktor resiko terkait, didapatkan tiga faktor umum yang diidentifikasi menjadi motivasi bermain adalah memperoleh achievement, sociability, dan mendapat Lukita J, William, Sumadikarya I dan Rumiati F. 2020;26(1):8-16 
pengakuan. ${ }^{17}$ Untuk memperoleh achievement, pemain diharuskan untuk selalu menjadi yang terbaik dengan cara menaikan level karakter di dalam game, upgrade status dan kekuatan karakter di dalam game, mendapatkan kemampuan untuk menantang dan mendominasi pemain lain. Reputasi dan rasa kagum dari sesama gamer di komunitas game sebagai hasil dari usaha bermain yang gigih dan terampil juga meningkatkan rasa bangga akan achievement yang didapat, sehingga mendorong gamer untuk mencurahkan lebih banyak waktu dan upaya untuk terus bermain. ${ }^{18}$

Dari hasil penelitian ini diperoleh 9,1\% dari responden mengalami internet gaming disorder dengan presentase yang tidak jauh berbeda antara responden pria dengan responden wanita. Didapatkan prevalensi gangguan internet gaming disorder pada responden pria $4,5 \%$ lebih banyak daripada responden wanita. Jumlah perbandingan presentase penderita gangguan internet gaming disorder berdasarkan jenis kelamin ini hampir mirip dengan penelitian yang dilakukan sebelum nya oleh Febriani dan Marcella di Fakultas Kedokteran Unika Atma Jaya tahun 2011. ${ }^{19}$

Dari hasil analisis statistik dapat dilihat bahwa ada korelasi lemah antara internet gaming disorder dengan kualitas tidur. Hasil dari korelasi yang lemah ini dapat disebabkan oleh beberapa faktor, salah satu nya usia responden. Dari hasil penelitian ini diperoleh $40,1 \%$ dari responden memiliki rentang usia 19-20 tahun. Hal ini didukung oleh penelitian yang dilakukan oleh Maya Samaha terhadap remaja berusia 15-19 tahun, didapatkan hasil bahwa risiko internet gaming disorder meningkat pada usia lebih muda. ${ }^{14}$ Faktor lain yang mungkin menyebabkan hasil korelasi lemah adalah penelitian ini menggunakan subjek mahasiswa kedokteran yang pada dasarnya mempunyai durasi tidur yang kurang dan kualitas tidur yang buruk $(98,6 \%)$. Hal ini didukung oleh penelitian yang dilakukan oleh Fenny dan Supriatmo terhadap 594 mahasiswa kedokteran di Fakultas Kedokteran Universitas Sumatera Utara dimana 54,3\% memiliki durasi tidur yang kurang dan $61,7 \%$ memiliki kualitas tidur yang buruk. ${ }^{20}$ Hasil $98,6 \%$ pada penelitian ini hampir mirip dengan penelitian yang dilakukan Riska terhadap 160 mahasiswa kedokteran di Fakultas Kedokteran Universitas Padjajaran dimana 95,6\% memiliki durasi tidur
$<6$ jam dan 93,8\% memiliki kualitas tidur yang buruk. ${ }^{21}$

Gamer dapat terjaga semalaman disebabkan karena pada saat bermain game, maka korteks cerebral akan mengeluarkan norepinepfrin dan dopamin. Kedua neurotransmitter tersebut bagian dari reticular activating system (RAS) yang berfungsi untuk mempertahankan keadaan terjaga. Selain itu cahaya yang dihasilkan ketika bermain menyebabkan terhambatnya produksi hormon melatonin yang dikeluarkan oleh hipotalamus yang menyebabkan seseorang tidak bisa segera melakukan aktivitas tidur. ${ }^{21}$

\section{Simpulan}

Waktu pergi tidur Mahasiswa FK Ukrida paling banyak pada jam 24.00-01.59. Waktu bangun tidur paling banyak diantara pukul 06.00-07.59. Waktu yang dibutuhkan untuk terlelap paling banyak $\leq 15$ menit. Responden paling banyak memiliki durasi tidur $<6$ jam per hari dengan rata-rata 5,5 jam per hari. Masalah yang paling banyak mengganggu tidur adalah tidak dapat tertidur selama 30 menit. Sebanyak 8 responden menggunakan obat-obatan untuk membantu tidur selama sebulan terakhir. Sebagian besar responden secara subjektif menilai kualitas tidur mereka baik. Gambaran internet gaming disorder pada mahasiswa FK Ukrida sebesar 9,1\% dari total populasi. Dalam penelitian ini, didapatkan hubungan antara internet gaming disorder dengan kualitas tidur Mahasiswa FK Ukrida tahun ajaran 2018/2019, tetapi hubungan yang didapatkan adalah lemah.

\section{Daftar Pustaka}

1. Brain basics: understanding sleep. Didapat dari: https://www.ninds.nih.gov/Disorders/Pa tient-Caregiver-

Education/Understanding-Sleep\#top [cited 14 Juni 2019];2019: [1 screen].

2. Circadian rhythms. Didapat dari: https://www.nigms.nih.gov/Education/P ages/Factsheet_CircadianRhythms.aspx [cited 14 Juni 2019];2017:[1 screen].

3. How sleep works. Didapat dari: https://www.nhlbi.nih.gov/healthtopics/how-sleep-works [cited 14 Juni 2019];2018:[1 screen]. 
4. Sherwood L. Susunan saraf pusat. Dalam: Yesdelita N, editor. Fisiologi manusia: dari sel ke sistem. Ed. 6. Jakarta: EGC. 2011

5. Amir, N. Tatalaksana insomnia: insomnia bisa terjadi pada semua lapisan usia, tak terkecuali anak-anak. Jakarta. 2010.

6. WHO menetapkan kecanduan game sebagai gangguan mental, bagaimana gamer Indonesia bisa sembuh. Didapat dari: https://theconversation.com/whotetapkan-kecanduan-game-sebagaigangguan-mental-bagaimana-gamerindonesia-bisa-sembuh-99029 [cited 29 agustus 2018];2012: [1 screen].

7. Rollings A, Adams E. Fundamentals of game design. Prentice Hall. 2006

8. Kuss DJ. Internet gaming addiction: current perspectives. Psychology Research and Behavior Management: 2013;6: 125-37. https://www.similarweb.com/apps/top/g oogle/store-rank/id/games/top-free.

9. American Psychiatric Association. Internet gaming. diagnostic and statistical manual of mental disorders, fifth edition. London: American Psychiatric Publishing. 2013.

10. International classification of disease for mortality and morbidity statistics. Didapat dari: https://www.who.int/classifications/icd/ en/

11. Kuss DJ, Louws J, Reinout WW. Online gaming addiction motives predict addictive play behavior in massively multiplayer online roleplaying games. Cyberpsychology Behavior and Social Networking. 2012;15(9): 480-5.

12. Pontes HM, Macur M, Griffiths MD. Internet gaming disorder among Slovenian primary schoolchildren finding from a nationally representative sample of adolescents. J Behav Addict. 2016;5(2): 304-10.

13. Maya S, Hawi NS, Griffiths MD. Internet gaming disorder in Lebanon relationships with age, sleep habits, and academic achievement. J Behav Addict. 2018;7(1): 70-8.

14. Choo $\mathrm{H}$ et al. Pathological video-gaming among Singaporean youth. Annals
Academy of Medicine. 2010;39(11): 822-9.

15. Spekman MLC, Konijn EA, Roelofsma PHMP, Griffiths MD. Gaming addiction, definition, and measurement a largescale empirical study. Computers in Human Behavior. 2013;29: 2150-5.

16. Hussain Z, Griffiths MD, Baguley T. Online gaming addiction classification prediction and associated risk factors. Addiction Research and Theory. 2012;20(5): 359-71.

17. Vollmer C, Randler C, Horzum MB, Ayas T. Computer game addiction in adolescents and its relationship to chronotype and personality. SAGE Open. 2014;4(1): 1-9.

18. Sari F, Auditta M. Pengaruh stres terhadap kualitas tidur pada mahasiswa fakultas kedokteran unika atma jaya angkatan 2010 [skripsi]. Jakarta: Fakultas Kedokteran Unika Atma Jaya. 2011.

19. Fenny, Supriatmo. Hubungan kualitas dan kuantitas tidur dengan prestasi belajar pada mahasiswa fakultas kedokteran. Jurnal Pendidikan Kedokteran Indonesia. November 2016;5(3): 140-7.

20. Riska S, Faisal, Huda F. Perbandingan kualitas tidur mahasiswa fakultas kedokteran universitas padjajaran yang menggunakan dan tidak menggunakan cahaya lampu saat tidur. JSK. Desember 2017;3(2): 73-9.

21. Indrawati. Hubungan permainan video game dengan pola tidur anak usia sekolah SD Muhammadiyah Condong Catur, Sleman [skripsi]. Yogyakarta: Fakultas Kedokteran dan Ilmu Kesehatan Universitas Muhammadiyah Yogyakarta. 2014. 